\title{
THE OCTOBER MEETING IN NEW YORK
}

The three hundred fifty-third meeting of the American Mathematical Society was held at Columbia University on Saturday, October 29, 1938. The attendance included the following one hundred thirty-three members of the Society:

E. B. Allen, C. B. Allendoerfer, R. L. Anderson, R. G. Archibald, Herbert E. Arnold, S. F. Barber, M. F. Becker, W. Johnston Berry, E. E. Betz, W. Z. Birnbaum, Samuel Borofsky, H. W. Brinkmann, A. A. F. Brown, A. B. Brown, J. H. Bushey, Jewell H. Bushey, S. S. Cairns, W. D. Cairns, A. D. Campbell, M. E. Carlen, L. W. Cohen, J. B. Coleman, T. F. Cope, Richard Courant, H. B. Curry, M. D. Darkow, Jesse Douglas, Arnold Dresden, W. D. Duthie, J. E. Eaton, H. T. Engstrom, Aaron Fialkow, F. A. Ficken, W. B. Fite, D. A. Flanders, Tomlinson Fort, R. M. Foster, J. S. Frame, Philip Franklin, K. O. Friedrichs, B. P. Gill, Saul Gorn, A. M. C. Grant, W. C. Graustein, M. C. Gray, M. B. Greenebaum, S. L. Greitzer, M. B. Haberzetle, D. W. Hall, Marshall Hall, N. A. Hall, Israel Halperin, D. C. Harkin, Philip Hartman, Alan Hazeltine, G. A. Hedlund, E. H. C. Hildebrandt, Einar Hille, Lulu Hofmann, T. R. Hollcroft, M. A. Holly, S. A. Joffe, A. W. Jones, B. W. Jones, E. R. van Kampen, Edward Kasner, B. F. Kimball, J. R. Kline, L. A. Knowler, B. O. Koopman, A. W. Landers, M. K. Landers, Solomon Lefschetz, Marie Litzinger, J. C. C. McKinsey, L. A. MacColl, H. F. MacNeish, Dorothy Manning, Walther Mayer, Karl Menger, G. R. Mirick, Marston Morse, Tadasi Nakayama, I. M. Niven, C. O. Oakley, Oystein Ore, Everett Pitcher, E. L. Post, R. G. Putnam, H. A. Rademacher, M. S. Rees, Moses Richardson, R. G. D. Richardson, J. F. Ritt, M. S. Robertson, S. L. Robinson, Benjamin Rosenbaum, S. G. Roth, Arthur Sard, C. H. W. Sedgewick, R. W. Sedgewick, Stephan Serghiesco, L. W. Sheridan, Max Shiffman, L. G. Simons, James Singer, L. L. Smail, P. A. Smith, N. E. Steenrod, M. H. Stone, W. C. Strodt, Alvin Sugar, M. M. Sullivan, J. D. Tamarkin, J. M. Thomas, E. W. Titt, J. W. Tukey, Annita Tuller, S. M. Ulam, Oswald Veblen, J. V. Wehausen, Louis Weisner, M. E. Wells, A. P. Wheeler, O. L. Wheeler, H. S. White, Norbert Wiener, Aurel Wintner, H. P. Wirth, Audrey Wishard, D. W. Woodard, H. N. Wright, Leo Zippin.

A general session was held Saturday morning and another in the afternoon. Professor A. D. Campbell and Vice President J. F. Ritt, respectively, presided. At the afternoon session, Professor G. A. Hedlund of Bryn Mawr College gave an address entitled The dynamics of geodesic flows.

The Organizing Committee of the International Congress of Mathematicians met in the Faculty Club of Columbia University at $3: 45$ P.M.

Titles and cross references to the abstracts of papers read at this meeting follow below. Papers numbered 1 to 9 were read at the morning session and those numbered 10 to 12 at the afternoon session. 
Papers numbered 13 to 30 , whose abstract numbers are followed by the letter $t$, were read by title. Professor G. H. Peebles was introduced by Professor Dunham Jackson.

1. Marshall Hall: A type of algebraic closure. (Abstract 44-9-342.)

2. Dorothy Manning: On simply transitive groups with transitive abelian subgroups of the same degree. III. (Abstract 44-9-398.)

3. L. A. MacColl: Differential-geometric aspects of relativistic $d y$ namics. (Abstract 44-9-397.)

4. H. W. Brinkmann: Relations between zeta-functions of different algebraic fields. (Abstract 44-11-406.)

5. Tomlinson Fort: The Euler-Maclaurin summation formula. (Abstract 44-11-410.)

6. Richard Courant: New remarks on Plateau's problem. (Abstract 44-11-408.)

7. T. R. Hollcroft: Curve systems with distinct nodes and cusps and of negative virtual dimension. (Abstract 44-11-412.)

8. F. A. Ficken: The Riemannian and affine differential geometry of product-spaces. (Abstract 44-11-409.)

9. M. S. Robertson: On certain power series having infinitely many zero coefficients. (Abstract 44-11-461.)

10. Jesse Douglas: Minimal surfaces of higher topological structure. II. (Abstract 44-11-458.)

11. Karl Menger: On non-euclidean and affine geometry. (Abstract 44-11-459.)

12. S. M. Ulam: On the distribution of a general measure in any complete metric separable space. (Abstract 44-11-462.)

13. Leonard Bristow: Expansion of functions in solutions of functional equations. (Abstract 44-11-457-t.)

14. Richard Courant: Conformal mapping of non-orientable surfaces on plane domains. (Abstract 44-11-407-t.)

15. Jesse Douglas: A Jordan space-curve having the infinite area property at each of its points. (Abstract 44-9-388-t.)

16. Jesse Douglas: The problem of Plateau. (Abstract 44-9-389-t.)

17. Jesse Douglas: Geometry of polygons in the complex plane. (Abstract 44-9-390-t.)

18. W. D. Duthie: Pseudo-valuation for Boolean rings. (Abstract 44-9-391-t.)

19. D. W. Hall and A. D. Wallace: Some invariants under monotone transformations. (Abstract 44-11-411-t.)

20. Edward Kasner and J. J. DeCicco: Conformal geometry of horn angles of second order contact. (Abstract 44-9-392-t.) 
21. K. W. Lamson: Linear families of linear $S_{2}$-complexes in $S_{5}$. (Abstract 44-9-394-t.)

22. A. N. Lowan: On Green's functions in the theory of heat conduction in spherical coordinates. (Abstract 44-11-413-t.)

23. A. N. Lowan: On the computation of certain infinite series. (Abstract 44-9-395-t.)

24. A. N. Lowan: On the computation of the second difference of the Si $(x), C i(x)$, and Ei(x) functions. (Abstract 44-11-414-t.)

25. A. N. Lowan: On wave motion for subinfinite domains. (Abstract 44-9-396-t.)

26. J. D. Mancill: Problems of the calculus of variations with prescribed transversality conditions. (Abstract 44-11-415-t.)

27. G. H. Peebles: Some generalizations of the theory of orthogonal polynomials. (Abstract 44-11-460-t.)

28. J. A. Shohat: On the generalized orthogonal polynomials. (Abstract 44-11-416-t.)

29. Louis Weisner: A characteristic property of completely decomposable groups. (Abstract 44-11-417-t.)

30. Louis Weisner: Condition that a finite group be multiply isomorphic with each of its irreducible representations. (Abstract 44-9403-t.)

T. R. Hollcroft, Associate Secretary 